\title{
HER2/Neu Positive by Immunohistochemistry 31-40 Percent
}

National Cancer Institute

\section{Source}

National Cancer Institute. HER2/Neu Positive by Immunohistochemistry 31-40 Percent. NCI Thesaurus. Code C141497.

An immunohistochemical staining finding indicating that 31-40 percent of the cells in a tissue sample are expressing receptor tyrosine-protein kinase erbB-2. 